\title{
Stable Interest Rates Follow Stable Prices
}

\author{
William T. Gavin
}

I

$\mathrm{n}$ the 1980s, the United States and most other developed countries adopted monetary policies based on the goal of first achieving, and then maintaining, price stability. Price stability can be defined as an economic environment in which people can make plans and contracts without worrying about inflation. Interest rates are a good indicator of expectations about future inflation because most long-term shifts in the level of interest rates are due to changes in the market's expectations about future inflation.

During the long period of achieving price stability in the United States-from about 1983 until the mid-1990sinterest rates declined. In 1984, the yields on the 3-month Treasury bill and the 10-year bond peaked at 10.90 percent and 13.56 percent, respectively. By 1993, the yield on the 3 -month bill had fallen to 3 percent and the yield on the 10 -year bond dipped to 5.33 percent. Since the mid-1990s, inflation and interest rates have been relatively stable, reflecting the relative success of monetary policy in maintaining price stability.

The table shows statistics for short- and long-term interest rates for two periods. The first period, from January 1983 until December 1996, is one of declining inflation and inflation expectations. The average 3-month interest rate over this period was 6.36 percent and the average 10 -year rate was 8.35 percent.

The second period, from January 1997 to the present, is one of relative price stability. A comparison of the two periods clearly shows the advantage of price stability: Interest rates shown in the bottom panel are, on average, 2 to 3 percentage points lower across all maturities, with the largest declines in the longest maturities. At the short end, monthly average rates have varied from a low of 0.90 percent to a high of 6.36 percent, which was the average in the earlier period. At the long end, the yield on 10-year bonds has averaged 5.02 percent and, on a monthly average basis, has never risen as high as 7 percent.

Another benefit of price stability is that it stabilizes people's expectations about inflation. Hence, indications of strong economic growth are less likely to foment expectations of a long-lasting shift in the inflation rate. Also, under price stability, monetary policymakers are less compelled to quell inflation fears during periods of fast economic growth by raising short-term interest rates. The table illustrates this benefit by showing the average monthly standard deviations of the respective interest rates, calculated from daily data. This measure shows that expectations in the current era of price stability have been well anchoredthat is, intra-month developments, such as data releases, have less effect on interest rates. 